\title{
РЕТРОСПЕКТИВНЕ ДОСЛІДЖЕННЯ ОНКОГІНЕКОЛОГІЧНОЇ ПАТОЛОГІї У 2015-2019 РОКАХ
}

\author{
Тернопільський національний медичний університет \\ імені І. Я. Горбачевського МОЗ України, м. Тернопіль, Україна
}

\begin{abstract}
Мета: вивчити захворюваність, смертність та фрактори ризику розвитку онкогінекологічної патології за 20152019 pp.

Матеріали і методи. Проаналізовано дані Національного канцер-реєстру України за 2015-2019 рр. Використано бібліосемантичний, епідеміологічний, аналітичний методи дослідження.

Результати. У статті наведено дані щодо захворюваності, смертності та фракторів ризику поширеності онкогінекологічних патологій репродуктивних органів - молочної залози, шийки та тіла матки. За період 2015-2019 рр. відзначено зростання захворюваності на рак молочної залози - 3 70,0 до 77,5 на 100 тис. жіночого населення. Серед фракторів ризику виникнення онкогінекологічних патологій виділяють вік (30-54 роки, 55-74 роки), раннє менархе, безпліддя та відсутність пологів, приймання оральних контрацептивів або замісної гормональної терапії, нерегулярні статеві відносини, жіноча самотність; наявність супутньої патології (цукровий діабет, гіпертензія, надлишкова маса тіла або ожиріння), генетична схильність; поведінкові ризики (низька фрізична активність, вживання алкоголю, тютюнокуріння як активне, так і пасивне).

Висновки. Результати проведених досліджень свідчать про необхідність удосконалення системи раннього виявлення та профрілактики онкогінекологічної патології. Існує потреба в створенні програмних заходів щодо раннього виявлення передпухлинних захворювань, своєчасного та якісного надання медичної допомоги хворим цієї категорії, а також сприянні загострення уваги самих жінок на проблемі раку та спонукати їх більш відповідально ставитись до власного здоров'я.
\end{abstract}

КЛЮчОВІ СЛОВА: рак молочної залози; рак шийки матки; рак тіла матки; захворюваність; фрактори ризику.

Проблема онкології давно вже переступила за рамки охорони здоров'я і стала серйозною соціальною проблемою. Оскільки смертність від злоякісних новоутворень (3Н) призводить до соціально-економічних втрат, це дає можливість розглядати боротьбу зі злоякісними новоутвореннями як державну проблему. Соціальна значущість онкогінекологічних хвороб визначається високими показниками захворюваності та смертності серед осіб працездатного та репродуктивного віку.

Мета роботи: вивчити захворюваність, смертність та фрактори ризику розвитку онкогінекологічної патології за 2015-2019 рр.

Матеріали і методи. Проаналізовано дані Національного канцер-реєстру України за 20152019 рр. Використано бібліосемантичний, епідеміологічний, аналітичний методи дослідження.

Результати дослідження та їх обговорення. Злоякісні пухлини жіночих репродуктивних органів займають провідні місця в структурі захворюваності як в Україні, так і цілому світі. Це зумовлено значним зростанням захворюваності на рак молочної залози, рак тіла матки (РТМ) і рак шийки матки (РШМ).

(c) Н. О. Теренда, Н. М. Гандзюк, 2021
На основі опрацьованих нами даних Національного канцер-реєстру України захворюваність жіночого населення на злоякісні новоутворення залишається стабільно високою і протягом останніх 5 років вона зросла із 358,8 на 100 тис. жіночого населення у 2015 р. до 375,9 на 100 тис. жіночого населення у 2019 р. Жінки, які проживають у великих містах, розвинених регіонах, хворіють на рак частіше, ніж мешканці сільської місцевості на 3,3 \%. Показник захворюваності на рак тіла матки зменшився з 32,4 на 100 тис. жіночого населення у 2015 р. до 31,6 на 100 тис. жіночого населення у 2019 р., на рак шийки матки зріс з 21,1 до 21,3 на 100 тис. жіночого населення відповідно, на рак молочної залози з 70,0 до 77,5 на 100 тис. жіночого населення відповідно. Найбільше захворюваності на злоякісні новоутворення серед жіночого населення в 2015-2019 рр. припадає на вік 60-80 років (рис. 1). Тобто злоякісне захворювання молочної залози спостерігали в більшості осіб зрілого та старшого віку. Захворюваність на рак молочної залози серед жіночого населення в Україні становила 70,3 випадку на 100 тис. населення у 2019 р., а в 2015 р. - 67,3 на 100 тис. населення. Це говорить про те, що спостерігається постійне зростання частоти цього захворювання. 


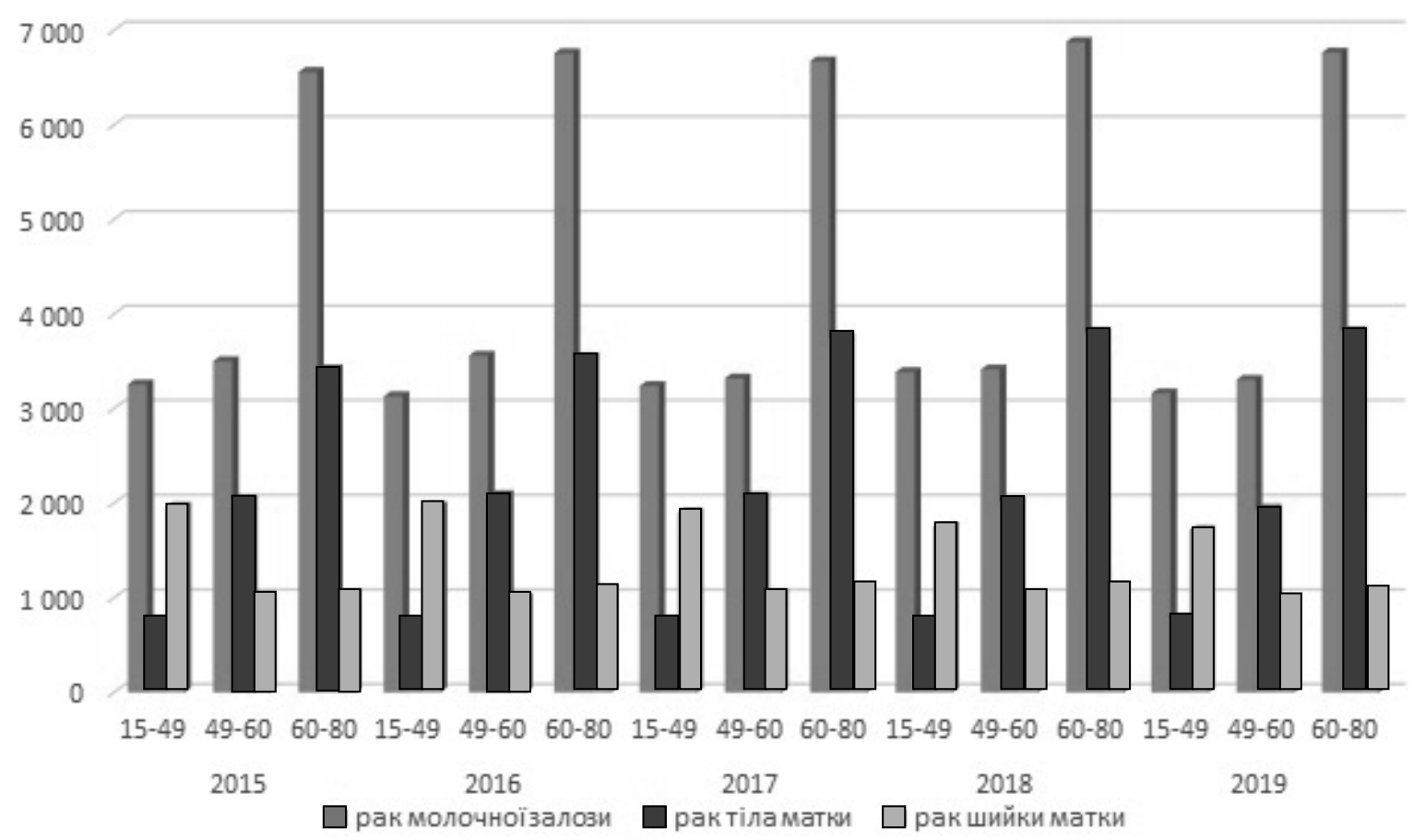

PUс. 1. Захворюваність на злоякісні новоутворення жіночої репродуктивної системи.

На основі проведеного аналізу даних ми спостерігали зростання захворювання у західному та північному регіонах України на 5,4-6,0 \% [1].

У Тернопільській області в 2019 р. зареєстровано 3482 випадки злоякісних новоутворень, в тому числі 1766 і 1716 серед чоловічого та жіночого населення відповідно (50,7 \% у чоловіків, 49,3 \% у жінок). На основі опрацьованих нами даних за 2015-2019 рр. у структурі захворюваності серед жіночого населення Тернопільської області спостерігали високі показники на злоякісні захворювання репродуктивної системи. Зокрема, на першому місці рак молочної залози становить 1553 випадки, на другому місці рак тіла матки 929 випадків і на третьому місці рак шийки матки 529 випадків. Таку структуру спостерігали і в 2019 p.
За даними Національного інституту раку, в 2019 р. рак молочної залози займає перше місце в структурі захворюваності (20,6 \%) і смертності (20,5 \%) серед жінок. Це зумовлює актуальність дослідження даної патології, а отримані статистичні дані можуть бути базою для розробки дій, спрямованих на покращення показників захворюваності та смертності від злоякісних новоутворень насамперед жіночої репродуктивної системи.

При аналізі вікових груп спостерігали різке збільшення чисельності онкогінекологічних захворювань в групах «30-54 роки» $\mathrm{i}$ «55-74 роки». Таким чином, найбільший рівень смертності на злоякісні захворювання жіночої репродуктивної системи мають місце у віці 30-54 роки та 55 і старше (рис. 2).

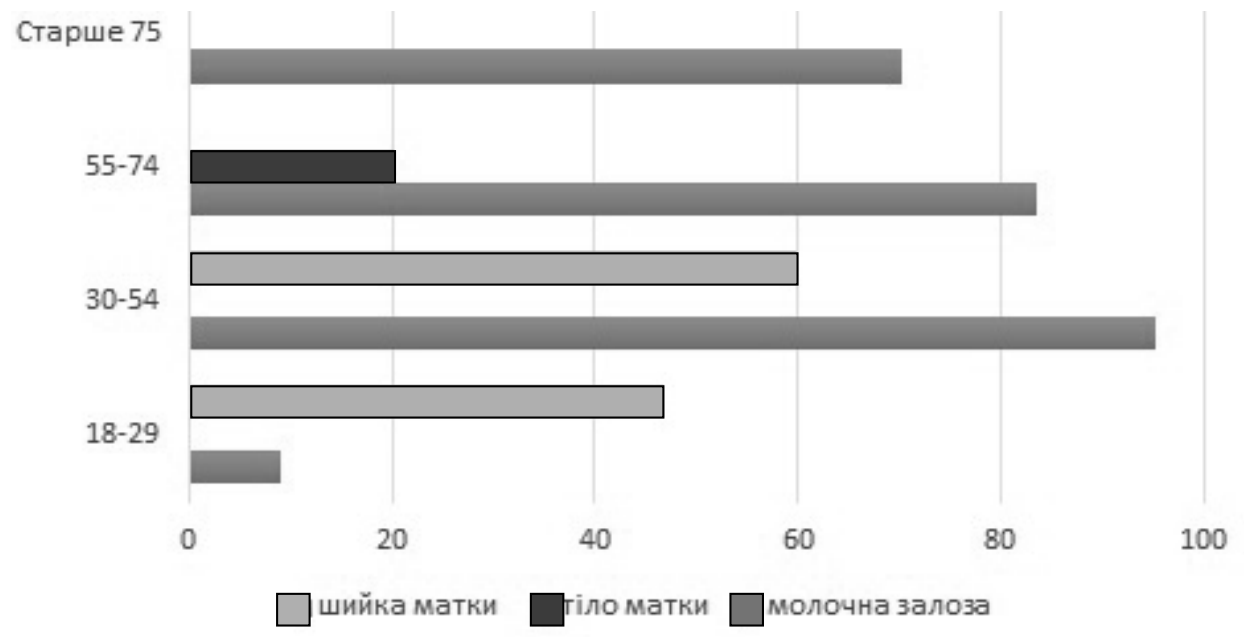

Рuc. 2. Смертність від злоякісних новоутворень жіночої репродуктивної системи за 2015-2019 рр. 
Захворювання на рак молочної залози $є$ найчастішою причиною смертності серед жінок у віці 30-54 роки (22,5-24,6 \%) і 55-74 роки (20,6-21,1 \%) відповідно. У віці 18-29 років спостерігали смертність від раку шийки матки у 8,4-14,1 \% випадків, у віці 30-54 роки смертність збільшується - 14,2-16,0 \%. Найменшу частку смертності від раку тіла матки спостерігали у віці 55-74 (6,5-6,9 \%).

Таким чином, найвищі показники смертності від злоякісних новоутворень серед жіночого населення становлять злоякісні утворення репродуктивної системи, зокрема рак молочної залози.

За даними різних дослідників, які вивчали епідеміологію злоякісних новоутворень репродуктивної системи, встановлено, що протягом останнього десятиріччя значно зросла кількість фракторів ризику розвитку онкогінекологічних захворювань. Останнє дослідники пов'язують із негативним впливом зовнішніх та внутрішніх чинників [4].

До фракторів ризику виникнення раку ендометрія належить раннє менархе, найчастіше у поєднанні 3 іншими проявами метаболічного синдрому, такими, як цукровий діабет, гіпертензія; безпліддя та відсутність пологів; гормонопродукуючі пухлини в анамнезі; доброякісні та передракові захворювання матки. Одним із ключових фракторів ризику розвитку раку тіла матки вважають спосіб життя 3 відсутністю фрізичної активності та переїданням (до 40 \% жінок $з$ діагнозом РТМ мають надлишкову масу тіла або ожиріння), відсутність статевого життя [5]. За даними різних дослідників, від 80 до 100 \% випадків РШМ асоційовані з вірусами папіломи людини (ВПЛ) високого канцерогенного ризику. Проведені дослідження показали, що ВПЛ визначали в $85 \%$ випадків у хворих на рак шийки матки в розвинених країнах та 91 \% випадків у країнах, що розвиваються. Ряд дослідників відзначає, що цервікальну інтраепітеліальну неоплазію найчастіше діагностували у жінок дітородного віку. У зв'язку з цим, вагітність належить до фракторів ризику розвитку цервікальної інтраепітеліальної неоплазії [6]. Ризик захворювання на рак молочної залози збільшується з віком. До груп ризику виникнення хвороби на рак молочної залози належать жінки, які в сімейному анамнезі мають випадки захворювання [3]. Серед фракторів ризику - ранній початок менструацій і пізній клімакс, приймання оральних контрацептивів або замісної гормональної терапії, вживання алкоголю. Жіноча самотність, відсутність стійких сімейних відносин, нерегулярні статеві відносини, цукровий діабет, гіпертонічна хвороба - все це сприяє розвитку патологічних процесів у молочній залозі [2].

Проведені епідеміологічні дослідження показали, що поведінкові ризики, зокрема вживання алкоголю, тютюнокуріння як активне, так і пасивне, низька фрізична активність призводять до розвитку раку молочної залози. У віці 1549 років відносний показник ризику розвитку раку молочної залози становить RR=24,17\% (19,71$28,73 \%)$, а раку шийки матки - RR=100 \%, серед жіночого населення у віці 50-69 років відносний показник ризику розвитку раку молочної залози складає RR=18,87 \% (15,24-22,52 \%), у той час відносний показник ризику розвитку раку шийки матки становить $\mathrm{RR}=100 \%$, у віці 70 років i старше аналогічно, фрактор ризику розвитку раку молочної залози у віці 70 років і старше становить $\mathrm{RR}=10,65 \%(7,77-13,21 \%)$.

\section{Висновки}

Результати проведених досліджень свідчать про необхідність удосконалення системи раннього виявлення та профрілактики онкогінекологічної патології. Існує потреба в створенні програмних заходів щодо раннього виявлення передпухлинних захворювань, своєчасного та якісного надання медичної допомоги хворим цієї категорії, а також сприянні загострення уваги самих жінок на проблемі раку та спонукати їх більш відповідально ставитись до власного здоров'я.

Перспективи подальших досліджень полягають у розробці та впровадженні програм профрілактики онкогінекологічної патології.

\section{Список літератури}

1. Бюлетень Національного канцер-реєстру України [Електронний ресурс] / [3. П. Федоренко, Л. О. Гулак, Ю. Й. Михайлович та ін.]. - 2019. - Режим доступу : http://www.ncru.inf.ua/publications/.

2. Методичні рекомендації для самопідготовки до семінарських занять лікарів-інтернів за фрахом «Клінічна онкологія», «Загальна практика - сімейна медицина», «Хірургія» / Є. С. Готько, С. В. Жеро, Д. Й. Цигика та ін. Ужгород : Ужгородський Національний Університет, 2011. - 21 с.

3. Онкологія : підручник / Ю. В. Думанський, А. І. Шевченко, І. Й. Галайчук та ін. ; за ред. Г. В. Бондаря, А. І. Шевченка, І. Й. Галайчука. - 2-ге вид., переробл. та доповн. - К. : ВСВ «Медицина», 2019. - 520 с.

4. Оновлені фрактори ризику в онкології [Електронний ресурс] // Ваше здоров'я. - 2019. - Режим доступу : https:// www.vz.kiev.ua/onovleni-faktory-ryzyku-v-onkologiyi/.

5. Романів М. П. Синоптична характеристика фракторів ризику виникнення раку тіла матки та раку яєчників / М. П. Романів, В. М. Михальчук // Вісник соціальної гігієни та організації охорони здоров'я України. - 2017. - № 3. C. 58-66. 
6. Estimates of incidence and mortality of cervical cancer in 2018: a worldwide analysis / [M. Arbyn, E. Weiderpass, L. Bruni et al.] // Lancet Glob Health. - 2020. - No. 8. - P. 191-203.

\section{References}

1. Fedorenko, Z.P., Hulak, L.O., Mykhaylovych, Yu.Y., Horokh Ye.L., Ryzhov A.Yu., Sumkina O.V., \& Kutsenko L.B. (2019). Byuleten Natsionalnoho kantser-reyestru Ukrayiny. - Bulletin of the National Cancer Registry of Ukraine. Retrieved from: http://www.ncru.inf.ua/publications/ [in Ukrainian].

2. Hotko, Ye.S., Zhero, S.V., \& Tsyhyka D.Y. (2011). Metodychni rekomendatsiyi dlya samopidhotovky do seminarskykh zanyat likariv-interniv za fakhom «Klinichna onkolohiya», «Zahalna praktyka - simeyna medytsyna», «Khirurhiya». [Methodical recommendations for self-preparation for seminars of interns in the specialty «Clinical Oncology», «General Practice - Family Medicine», «Surgery»]. Uzhhorodskyi natsionalnyi universytet - Uzhhorod National University, 21[in Ukrainian].

3. Dumanskyy, Yu.V., Shevchenko, A.I., Halaychuk, I.Y., \& Bondar, H.V. (2019). Onkolohiya: pidruchnyk [Oncology: handbook]. Kyyiv: VSV «Medytsyna» [in Ukrainian].

4. (2019). Onovleni faktory ryzyku v onkolohiyi [Updated risk factors in oncology]. Vashe zdorovya. - Your Health. Retrieved from: https://www.vz.kiev.ua/onovleni-faktory-ryzyku-v-onkologiyi/ [in Ukrainian].

5. Romaniv, M.P., \& Mykhalchuk, V.M. (2017). Synoptychna kharakterystyka faktoriv ryzyku vynyknennya raku tila matky ta raku yayechnykiv [Synoptic characteristics of risk factors for uterine body cancer and ovarian cancer]. Visnyk sotsialnoyi hihiyeny ta orhanizatsiyi okhorony zdorovya Ukrayiny. - Bulletin of Social Hygiene and Health Care Organization of Ukraine, 3, 58-66 [in Ukrainian].

6. Arbyn, M., Weiderpass, E., \& Bruni, L. (2020). Estimates of incidence and mortality of cervical cancer in 2018: a worldwide analysis. Lancet Glob. Health, 8, 191-203.

\section{RETROSPECTIVE STUDY OF ONCOGYNECOLOGICAL PATHOLOGY IN 2015-2019}

N. O. Terenda, N. M. Handziuk

I. Horbachevsky Ternopil National Medical University, Ternopil, Ukraine

Purpose: to study morbidity, mortality, and risk factors for oncogynecological pathology development in 2015-2019.

Materials and Methods. The data of the National Cancer Register of Ukraine in the period of 2015-2019 were analyzed. Bibliosemantic, epidemiological, and analytical research methods were used.

Results. The article presents data on morbidity, mortality, and risk factors for the prevalence of oncogynecological pathologies of the reproductive organs, namely mammary glands, cervix, and uterine body. There was an increase in the incidence of breast cancer in the period of 2015-2019. It was from 70.0 to 77.5 per 100 thousand female population.

Among the risk factors of oncogynecological pathologies occurrence are age (30-54 years, 55-74 years), early menarche, infertility and lack of childbirth, the use of oral contraceptives or hormone replacement therapy, irregular sexual relationships, female loneliness; the presence of concomitant pathology (diabetes, hypertension, overweight or obesity); genetic predisposition; behavioral risks (low physical activity, alcohol consumption, tobacco smoking, both active and passive).

Conclusions. As a result of the conducted research, there is a need to improve the system of early detection and prevention of oncogynecological pathology. There is a need to create programmatic measures for early detection of precancerous diseases, timely and high-quality medical care for patients of this category, as well as to help focus women's attention on the problem of cancer and encourage them to take a more responsible attitude to their health.

KEY WORDS: breast cancer; cervical cancer,; uterine body cancer; morbidity; risk factors.

Рукопис надійшов до редакції 12.01.2021 р.

Відомості про авторів:

Теренда Наталія Олександрівна - доктор медичних наук, професор кафедри громадського здоров'я та управління охороною здоров'я Тернопільського національного медичного університету імені І. Я. Горбачевського МОЗ України; тел.: +38(0352) 52-72-33.

Гандзюк Надія Михайлівна - асистент кафедри медичної інформатики Тернопільського національного медичного університету імені І. Я. Горбачевського МОЗ України; тел.: +38(0352) 52-09-90. 